\title{
EFFECTS ON LABOUR AND GDP OF THE CAP 2013 REFORM THOUGH INVESTMENT IN AGRICULTURAL MACHINERY: SPANISH CASE
}

Núm. 1(2013), pp. 169-203.

Carolina Cosculluela-Martínez ${ }^{1}$.

Recibido: Junio, 2013

Aceptado: Septiembre, 2013

JEL Clasif: $\mathrm{C}_{3}, \mathrm{C}_{5}, \mathrm{~J}_{4}, \mathrm{O}_{4}$

\footnotetext{
${ }^{1}$ Universidad Rey Juan Carlos (Madrid. Spain). cosculluela.c@gmail.com
} 


\begin{abstract}
This paper studies the effect of the investment in agricultural machinery on the Spanish net employment and GDP growth. Those dynamic responses to a permanent unitary shock in agricultural machinery capital stock are studied estimating a reduced form of a Structural Equation Model (SEM) where effects on all variables are considered. Results suggest that CAP 2013 negotiation in Brussels is crucial for the Spanish 25\% unemployment rate. The investment of 4,5 thousand Euro increases net employment in one employee after 4 years, while other machinery requires 24,7 thousand Euro and metal machinery 47,2 thousand Euro for the same achievement.
\end{abstract}

Key Words: CAP; Econometric modelling; agricultural; farmer and fishing machinery capital stock; Gross Domestic Product (GDP); Labour.

\title{
Resumen
}

Se estudian los efectos que produce sobre el empleo neto y el PIB la inversion en maquinaria para la agricultura, ganadería y pesca. Se estudian las respuestas dinámicas a un shock unitario permanente en el stock de capital de maquinaria para la agricultura, ganadería y pesca mediante la estimación de la forma reducida de un modelo de ecuaciones estructurales, donde se permiten los efectos entre todas las variables. Los resultados sugieren que la negociación de la PAC en 2013 es crucial en el desempleo de España. La inversion de 4,500 euros genera unos efectos remanentes al cabo de cuatro años de incremento del empleo neto en un empleado, mientras que si la inversion se realiza en cualquier otra maquinaria se precisan 5,5 veces ese capital y 10,5 veces ese capital si la inversion se realiza en maquinaria metálica.

Palabras Clave: PAC; modelización econométrica; stock de capital agrícola ganadera y pesquera; PIB; empleo. 


\section{Introduction.}

In this paper it is argued that the agricultural sector is a very important sector for the Spanish Economy. Thus the political reform of the CAP (Common Agricultural Policy) that should take place along 2013, would have to redefine the new necessities of this sector in order to respond to a necessary and possible sector growth. Those necessities are not, anymore, to correct the excess in production as in 1992, by restrictions in the quantity produced or lowering institutional prices across direct payments to producers, as the demand of food has increased accordingly to the extended EU (European Union) to the East and the generalized healthy consciousness of people in the developed countries.

Ulrich K. (2010) studies old and new policies. One of the new policy core subjects seem to be: $\left(1^{\text {st }}\right)$ Create a competitive agricultural sector without excessive funds; $\left(2^{\text {nd }}\right)$ New production machinery to increase production, quality and security and diversity in food production; $\left(3^{\text {rd }}\right)$ Maintenance of agricultural industry to promote agricultural employment; $\left(4^{\text {th }}\right)$ Preserve the environment and natural resources; and $\left(5^{\text {th }}\right)$ New global community policies and the needed public services to the agricultural sector. Thus, investment in machinery and R\&D (Research and Development). Accordingly, the effects of the investment in machinery is going to be evaluated in this paper.

To evaluate public investment in the agricultural sector on the Spanish economy is the main objective in this paper. It is done by studying the effects on GDP growth and net employment of a permanent unitary shock in agricultural, farmer and fishing machinery capital stock in the Spanish economy, whose industrial and construction sector is being reduced considerably during the actual international crisis, so other type of machinery (metal machinery and other machinery and software) is also evaluated in order to rank the effects of different types of machinery in different time span. Aggregated machinery is also evaluated to consider spillover effects of machinery on complementary machinery capital stock.

How are they going to be estimated? We use a dynamic, conceptual framework, similar to the one used by Flores et al (1998), which is a multi-equation, dynamic theoretical framework, so the possible presence of dynamic relations among all variables in the information set is considered, including feedback relationships and it does not constrain on a priori grounds the statistical properties of any time series 
included in the information set. Thus, time series can be non-stationary and there can be co-integration relations among them. The model can be seen as a pseudo-structural, multi-equation model where the identifying restrictions are clearly stated.

The methodology was previously used in many studies such as Cosculluela and Flores (2012) to evaluate housing investment on the Spanish economy. The framework used allows the isolation of responses to shocks in both, agricultural, fishing and farming machinery capital stock (and in order to compare, metal machinery and other machinery and software) and/or the complementary capital stock. This gives the possibility to study the effects -on labour and production- of different investment distributions, at different terms. Therefore, this model wants to be a useful macroeconomic policy instrument for quantifying the impact of the 2013 negotiation of the CAP founds, which represent almost $47 \%$ of the $€ 864.3$ billion EUs budget for the period 2007-2013 which is the largest single expenditure item.

The hypothesis of public capital being an important engine for economic growth, and therefore CAP founds invested in machinery, is based in the results of more than fifty papers published since late 80's. Each of them has been carried out in a different way making the results attained difficult to compare. Some used time series data, others cross-section data; some first-differenced series, others data in log-levels; some capital stock series, others investment series; some national data, others regional data; some used static econometric models, others dynamic ones; some single-equation models, and others multi-equation ones. Thus, there exist a great amount of results, which are difficult to compare; however, most of them hold that public capital can be consider an important engine of economic growth.

Differences are due to: (1) The use of different methodologies; (2) The use of different capital data series (investment versus stock); (3) Differences in the way capital stock series are computed; and, (4) different aggregations of the assets in each one of the series. Summarising:

(1) The use of different methodologies. Authors using a static framework, estimating a single static equation, consider that the elasticity is constant along time, when this one is only considering direct effects, unless the estimated equation is a cointegration relationship. However, elasticity estimated in dynamic frameworks considers direct and indirect effects, which, as it has been noted previously (section II), make the elasticity vary along time. Thus, the elasticity estimated in 
Effects on Labour and GDP of the CAP 2013 reform though investment in agricultural machinery: Spanish case

static equations does not consider long-run total effect, they use to be lower, and hardly to compare, to those estimated through the use of dynamic frameworks.

(2) The use of different capital data series (investment versus stock). Authors who use investment series do not take into account the effects of the existing capital, while the ones that use capital stock series consider that the effect of an investment depends on the existing capital stock of the asset that it is being considered. Thus, when studies with different methodologies are compared, the different types of series produce different effects on the variables. In studies using capital stock series the estimated elasticity are higher than in studies using investment series.

(3) Differences in the way capital stock series are computed. Capital stock series used by different authors have been obtained from different sources, and for that reason computed in heterogenic manners (different depreciation rates, different initial capital stock levels, different periods for the initial capital stock level, etc). The absence of homogeneity not only makes it difficult to compare between countries, also the series used for Spain has been obtained from different sources so they were difficult to compare to those obtained in this research. Nevertheless, even though capital stock series are computed in different ways, at the same time that the period in which the investment is made and, for that reason, the initial existent capital stock level, the sign (positive sign) of the estimated elasticity are the same to the ones in the literature.

(4) Different aggregations of the assets in each one of the series. Most of the authors considered two types of capital (private and public capital), and the ones that consider the type of asset, use only public investment series (in each type of asset). Thus, the elasticity of output to any capital stock series that includes a certain type of asset (no matter if it is public or private) is higher, although the same sign, that the elasticity of output to a capital stock or investment series of that certain type of asset.

Thus, results of this paper match up with the ones in the literature in the sign of the elasticity and the complementarity of machinery capital stock and labour in the production function. 
The differences in the magnitude of the elasticity that could be found with the studies that use similar methodology are based in the consideration of the investment in one certain type of asset is higher to the one that is produced by one investment that is not considering the existent capital or that only considers public existent capital stock. This produces as it was noted by Flores et al (1998) that the estimated elasticity of labour are higher than the ones in the literature, even explains negative elasticity of labour obtained by the other authors because the production system tends to substitute labour for capital due to technological changes that increases its productivity.

To evaluate the effects of agricultural, fishing and farming machinery instead of using as in Pereira and Andráz (2005) for the study of different types of transportation investment (national and regional roads, highways, ports, airports and railways) in Portugal investment series, capital stock series have been used to consider all existent capital. Thus, not only aggregated machinery capital stock is considered but also 3 disaggregated capitals. No work can be found studying capital stock effects on labour and GDP of agricultural, farmer and fishing machinery for the Spanish economy, nor for the USA economy. The type of data is crucial for any empirical analysis; authors use the best ones they can get according to their objectives. Generally they cannot do much about it, but study its statistical properties: order of integration, heteroscedasticity, type of autocorrelation, presence of outliers, etc.

The choice of the econometric model it is also crucial for the quality and reliability of the final results, but unlike the data choice procedure, here the researcher has much more responsibility. A wrong econometric methodology will impose incompatible constrains with data statistical properties; unnecessary restrictions are misspecification errors that will lead to a lack of consistency of the estimates. Ignoring the properties of time series, such as non-stationary behaviours, presence of co-integration, feedbacks or any other type of dynamics among the variables considered, will cause errors when specifying the model; and those will produce significant biases that will not die out, even when raising the sample size.

Recognizing time series statistical properties generally obliges to work in a multiequation framework, where one shock in one of the variables not only could vary the value of another one instantaneously, but its whole growing path, even the growing path of the first one when feedbacks are present. In a multi-equation framework elasticity are not constant over time; they usually vary with the term considered. The 
Effects on Labour and GDP of the CAP 2013 reform though investment in agricultural machinery: Spanish case

short-run elasticity (one or two periods) will be different to the instantaneous ones, and to the medium-run elasticity (three or four periods), or to the long-run elasticity (more than four periods). It makes no sense to compare elasticity without taking into account the period of response, which it is not normally mentioned.

The econometric methodology used, not only takes into account data statistical properties, but also allows for identifying structural responses to shocks in the 4 different types of capital stock assets. Thus, it allows the estimation in a consistent manner, of the Impulse Response Functions (IRF) of labour and GDP to those shocks taking into account the complementary capital.

Most of the papers analysing the effect of public capital stock have been published before 1997. They do not consider statistical properties of time series so results are not reliable. Most of them ignore that production; employment and capital stock time series are not stationary. The ones that do not ignore it do not take into account the possible feedback effects between capital stock, employment and output. Surprisingly, most of them attain the same conclusion: public capital stock is productive and an important engine for the economic growth.

The hypothesis behind the model used is, not only that public investment is productive if the investment is made in any kind of machinery, not even that the effects on GDP and employment are different if the investment is made in one type of machinery or the other, considering feedback effects and possible contemporaneous effects of complementary capital on the capital that is going to be studied, adapting Flores et al (1998) methodology to our purpose, those investments in machinery are going to be ranked to evaluate the path that the Spanish economy should follow to grow constantly.

The rest of the paper is organized as follows. Section II (Results) discusses the step response functions (SRFs) of output and employment. Section III shows the new version of the theoretical framework, presents the time series used, their statistical properties and the empirical estimation of the theoretical model; and provides a comparative analysis with the results in previous literature. Section IV concludes.

Results. SRFs From the Orthogonalized Reduced Form.Table 1 to 
Table 4 show the computed responses of output, employment, complementary capital stock and feedback effects, in percentage points, for each of the following 20 periods, to a permanent, one percentage point increase in the level of aggregated and disaggregated capital stock. Bootstrap bounds at $70 \%$ confidence level are also provided.

Table 1 Response functions (\%) of each variable level to a permanent unitary shock in aggregated machinery capital stock

\begin{tabular}{|c|c|c|c|c|c|c|c|c|c|c|c|c|}
\hline Period & LB & $\ln \mathrm{Y}$ & UB & $\mathrm{LB}$ & $\ln \mathrm{L}$ & UB & LB & $\ln \bar{K}_{4}$ & UB & LB & $\ln \mathrm{K}_{4}$ & UB \\
\hline 1 & 0.34 & 0.55 & 0.84 & 0.34 & 0.64 & 0.99 & 0.00 & 0.00 & 0.00 & 0.93 & 1.00 & 1.21 \\
\hline 2 & 0.24 & 0.39 & 0.57 & 0.37 & 0.79 & 1.22 & 0.00 & 0.00 & 0.00 & 1.33 & 1.48 & 1.87 \\
\hline 3 & 0.21 & 0.37 & 0.57 & 0.31 & 0.66 & 1.01 & 0.00 & 0.00 & 0.00 & 1.42 & 1.69 & 2.19 \\
\hline 4 & 0.16 & 0.33 & 0.51 & 0.28 & 0.60 & 0.91 & 0.00 & 0.00 & 0.00 & 1.39 & 1.73 & 2.30 \\
\hline 5 & 0.15 & 0.30 & 0.45 & 0.33 & 0.61 & 0.93 & 0.00 & 0.00 & 0.00 & 1.36 & 1.73 & 2.31 \\
\hline 6 & 0.15 & 0.28 & 0.43 & 0.33 & 0.63 & 0.96 & 0.00 & 0.00 & 0.00 & 1.36 & 1.73 & 2.33 \\
\hline 7 & 0.15 & 0.30 & 0.45 & 0.31 & 0.63 & 0.96 & 0.00 & 0.00 & 0.00 & 1.33 & 1.75 & 2.33 \\
\hline 8 & 0.15 & 0.30 & 0.45 & 0.33 & 0.63 & 0.96 & 0.00 & 0.00 & 0.00 & 1.33 & 1.75 & 2.33 \\
\hline 9 & 0.15 & 0.30 & 0.45 & 0.33 & 0.63 & 0.96 & 0.00 & 0.00 & 0.00 & 1.34 & 1.75 & 2.33 \\
\hline 10 & 0.16 & 0.30 & 0.45 & 0.34 & 0.63 & 0.96 & 0.00 & 0.00 & 0.00 & 1.34 & 1.75 & 2.33 \\
\hline 11 & 0.16 & 0.30 & 0.45 & 0.33 & 0.63 & 0.96 & 0.00 & 0.00 & 0.00 & 1.34 & 1.75 & 2.33 \\
\hline 12 & 0.16 & 0.30 & 0.45 & 0.33 & 0.63 & 0.96 & 0.00 & 0.00 & 0.00 & 1.34 & 1.75 & 2.33 \\
\hline 13 & 0.16 & 0.30 & 0.45 & 0.33 & 0.63 & 0.96 & 0.00 & 0.00 & 0.00 & 1.34 & 1.75 & 2.33 \\
\hline 14 & 0.16 & 0.30 & 0.45 & 0.34 & 0.63 & 0.96 & 0.00 & 0.00 & 0.00 & 1.34 & 1.75 & 2.33 \\
\hline 15 & 0.16 & 0.30 & 0.45 & 0.33 & 0.63 & 0.96 & 0.00 & 0.00 & 0.00 & 1.34 & 1.75 & 2.33 \\
\hline 16 & 0.16 & 0.30 & 0.45 & 0.33 & 0.63 & 0.96 & 0.00 & 0.00 & 0.00 & 1.34 & 1.75 & 2.33 \\
\hline 17 & 0.16 & 0.30 & 0.45 & 0.33 & 0.63 & 0.96 & 0.00 & 0.00 & 0.00 & 1.34 & 1.75 & 2.33 \\
\hline 18 & 0.16 & 0.30 & 0.45 & 0.33 & 0.63 & 0.96 & 0.00 & 0.00 & 0.00 & 1.34 & 1.75 & 2.33 \\
\hline 19 & 0.16 & 0.30 & 0.45 & 0.33 & 0.63 & 0.96 & 0.00 & 0.00 & 0.00 & 1.34 & 1.75 & 2.33 \\
\hline 20 & 0.16 & 0.30 & 0.45 & 0.33 & 0.63 & 0.96 & 0.00 & 0.00 & 0.00 & 1.34 & 1.75 & 2.33 \\
\hline
\end{tabular}

Notes: $\left(^{*}\right)$ Response functions of natural logarithms of each variable. LB and UB represents the lower and upper Bootstrap Bounds at 70\% confidence level, respectively. 
Effects on Labour and GDP of the CAP 2013 reform though investment in agricultural machinery: Spanish case

Table 2 Response functions (\%) of each variable level to a permanent unitary shock in agricultural, farmer and fishing machinery capital stock

\begin{tabular}{lllllllllllll} 
Period & LB & ln Y & UB & LB & ln L & UB & LB & ln K $K_{4-1}$ & UB & LB & ln $\mathrm{K}_{4-1}$ & UB \\
\hline 1 & 0.00 & 0.00 & 0.00 & 0.03 & 0.06 & 0.11 & 0.00 & 0.00 & 0.00 & 0.77 & 1.00 & 1.42 \\
\hline 2 & 0.01 & 0.02 & 0.04 & 0.04 & 0.07 & 0.13 & 0.00 & 0.00 & 0.00 & 0.77 & 1.00 & 1.42 \\
\hline 3 & 0.02 & 0.03 & 0.05 & 0.04 & 0.06 & 0.10 & 0.00 & 0.00 & 0.00 & 0.77 & 1.00 & 1.42 \\
\hline 4 & 0.02 & 0.03 & 0.05 & 0.03 & 0.05 & 0.10 & 0.00 & 0.00 & 0.00 & 0.77 & 1.00 & 1.42 \\
\hline 5 & 0.01 & 0.02 & 0.05 & 0.03 & 0.05 & 0.10 & 0.00 & 0.00 & 0.00 & 0.77 & 1.00 & 1.42 \\
\hline 6 & 0.01 & 0.02 & 0.05 & 0.03 & 0.05 & 0.10 & 0.00 & 0.00 & 0.00 & 0.77 & 1.00 & 1.42 \\
\hline 7 & 0.01 & 0.03 & 0.05 & 0.03 & 0.05 & 0.10 & 0.00 & 0.00 & 0.00 & 0.77 & 1.00 & 1.42 \\
\hline 8 & 0.01 & 0.03 & 0.05 & 0.03 & 0.05 & 0.10 & 0.00 & 0.00 & 0.00 & 0.77 & 1.00 & 1.42 \\
\hline 9 & 0.01 & 0.03 & 0.05 & 0.03 & 0.05 & 0.10 & 0.00 & 0.00 & 0.00 & 0.77 & 1.00 & 1.42 \\
\hline 10 & 0.01 & 0.03 & 0.05 & 0.03 & 0.05 & 0.10 & 0.00 & 0.00 & 0.00 & 0.77 & 1.00 & 1.42 \\
\hline 11 & 0.01 & 0.03 & 0.05 & 0.03 & 0.05 & 0.10 & 0.00 & 0.00 & 0.00 & 0.77 & 1.00 & 1.42 \\
\hline 12 & 0.01 & 0.03 & 0.05 & 0.03 & 0.05 & 0.10 & 0.00 & 0.00 & 0.00 & 0.77 & 1.00 & 1.42 \\
\hline 13 & 0.01 & 0.03 & 0.05 & 0.03 & 0.05 & 0.10 & 0.00 & 0.00 & 0.00 & 0.77 & 1.00 & 1.42 \\
\hline 14 & 0.01 & 0.03 & 0.05 & 0.03 & 0.05 & 0.10 & 0.00 & 0.00 & 0.00 & 0.77 & 1.00 & 1.42 \\
\hline 15 & 0.01 & 0.03 & 0.05 & 0.03 & 0.05 & 0.10 & 0.00 & 0.00 & 0.00 & 0.77 & 1.00 & 1.42 \\
\hline 16 & 0.01 & 0.03 & 0.05 & 0.03 & 0.05 & 0.10 & 0.00 & 0.00 & 0.00 & 0.77 & 1.00 & 1.42 \\
\hline 17 & 0.01 & 0.03 & 0.05 & 0.03 & 0.05 & 0.10 & 0.00 & 0.00 & 0.00 & 0.77 & 1.00 & 1.42 \\
\hline 18 & 0.01 & 0.03 & 0.05 & 0.03 & 0.05 & 0.10 & 0.00 & 0.00 & 0.00 & 0.77 & 1.00 & 1.42 \\
\hline 19 & 0.01 & 0.03 & 0.05 & 0.03 & 0.05 & 0.10 & 0.00 & 0.00 & 0.00 & 0.77 & 1.00 & 1.42 \\
\hline 20 & 0.01 & 0.03 & 0.05 & 0.03 & 0.05 & 0.10 & 0.00 & 0.00 & 0.00 & 0.77 & 1.00 & 1.42 \\
\hline & 0 & $(* 0$ & Reo &
\end{tabular}

Notes: $\left(^{*}\right)$ Response functions of natural logarithms of each variable. LB and UB represents the lower and upper Bootstrap Bounds at 70\% confidence level, respectively. 
Table 3 Response functions (\%) of each variable level to a permanent unitary shock in metal machinery capital stock

\begin{tabular}{lllllllllllll} 
Period & LB & ln Y & UB & LB & ln L & UB & LB & ln K $4-2$ & UB & LB & ln $\mathrm{K}_{4-2}$ & UB \\
\hline 1 & 0.32 & 0.61 & 0.88 & 0.38 & 0.59 & 1.00 & 0.00 & 0.00 & 0.00 & 0.94 & 1.00 & 1.23 \\
\hline 2 & 0.21 & 0.38 & 0.61 & 0.50 & 0.73 & 1.21 & 0.00 & 0.00 & 0.00 & 1.41 & 1.48 & 1.92 \\
\hline 3 & 0.23 & 0.36 & 0.59 & 0.42 & 0.62 & 1.06 & 0.00 & 0.00 & 0.00 & 1.52 & 1.70 & 2.24 \\
\hline 4 & 0.20 & 0.32 & 0.53 & 0.36 & 0.56 & 0.94 & 0.00 & 0.00 & 0.00 & 1.48 & 1.74 & 2.35 \\
\hline 5 & 0.18 & 0.27 & 0.47 & 0.35 & 0.58 & 0.95 & 0.00 & 0.00 & 0.00 & 1.47 & 1.76 & 2.38 \\
\hline 6 & 0.17 & 0.27 & 0.45 & 0.38 & 0.59 & 0.98 & 0.00 & 0.00 & 0.00 & 1.45 & 1.76 & 2.39 \\
\hline 7 & 0.18 & 0.27 & 0.45 & 0.38 & 0.59 & 1.00 & 0.00 & 0.00 & 0.00 & 1.44 & 1.77 & 2.39 \\
\hline 8 & 0.18 & 0.27 & 0.47 & 0.38 & 0.59 & 0.98 & 0.00 & 0.00 & 0.00 & 1.41 & 1.77 & 2.41 \\
\hline 9 & 0.18 & 0.27 & 0.47 & 0.38 & 0.59 & 0.98 & 0.00 & 0.00 & 0.00 & 1.39 & 1.77 & 2.41 \\
\hline 10 & 0.18 & 0.27 & 0.47 & 0.38 & 0.59 & 0.98 & 0.00 & 0.00 & 0.00 & 1.39 & 1.77 & 2.41 \\
\hline 11 & 0.18 & 0.27 & 0.47 & 0.38 & 0.59 & 0.98 & 0.00 & 0.00 & 0.00 & 1.39 & 1.77 & 2.41 \\
\hline 12 & 0.18 & 0.27 & 0.47 & 0.38 & 0.59 & 0.98 & 0.00 & 0.00 & 0.00 & 1.39 & 1.77 & 2.41 \\
\hline 13 & 0.18 & 0.27 & 0.47 & 0.38 & 0.59 & 0.98 & 0.00 & 0.00 & 0.00 & 1.39 & 1.77 & 2.41 \\
\hline 14 & 0.18 & 0.27 & 0.47 & 0.38 & 0.59 & 0.98 & 0.00 & 0.00 & 0.00 & 1.39 & 1.77 & 2.41 \\
\hline 15 & 0.18 & 0.27 & 0.47 & 0.38 & 0.59 & 0.98 & 0.00 & 0.00 & 0.00 & 1.39 & 1.77 & 2.41 \\
\hline 16 & 0.18 & 0.27 & 0.47 & 0.38 & 0.59 & 0.98 & 0.00 & 0.00 & 0.00 & 1.39 & 1.77 & 2.41 \\
\hline 17 & 0.18 & 0.27 & 0.47 & 0.38 & 0.59 & 0.98 & 0.00 & 0.00 & 0.00 & 1.39 & 1.77 & 2.41 \\
\hline 18 & 0.18 & 0.27 & 0.47 & 0.38 & 0.59 & 0.98 & 0.00 & 0.00 & 0.00 & 1.39 & 1.77 & 2.41 \\
\hline 19 & 0.18 & 0.27 & 0.47 & 0.38 & 0.59 & 0.98 & 0.00 & 0.00 & 0.00 & 1.39 & 1.77 & 2.41 \\
\hline 20 & 0.18 & 0.27 & 0.47 & 0.38 & 0.59 & 0.98 & 0.00 & 0.00 & 0.00 & 1.39 & 1.77 & 2.41 \\
\hline & 0.40 & Reo &
\end{tabular}

Notes: $\left.{ }^{*}\right)$ Response functions of natural logarithms of each variable. LB and UB represents the lower and upper Bootstrap Bounds at 70\% confidence level, respectively. 
Effects on Labour and GDP of the CAP 2013 reform though investment in agricultural machinery: Spanish case

Table 4 Response functions (\%) of each variable level to a permanent unitary shock in non-specialized machinery and software capital stock

\begin{tabular}{lllllllllllll}
\hline Period & LB & $\ln \mathrm{Y}$ & $\mathrm{UB}$ & $\mathrm{LB}$ & $\mathrm{ln} \mathrm{L}$ & $\mathrm{UB}$ & $\mathrm{LB}$ & $\mathrm{ln} \mathrm{K}_{4-3}$ & $\mathrm{UB}$ & $\mathrm{LB}$ & $\ln \mathrm{K}_{4-3}$ & $\mathrm{UB}$ \\
\hline 1 & -0.10 & 0.01 & 0.13 & -0.06 & 0.05 & 0.21 & 0.00 & 0.00 & 0.00 & 0.95 & 1.00 & 1.15 \\
\hline 2 & -0.05 & 0.01 & 0.10 & -0.07 & 0.06 & 0.26 & 0.00 & 0.00 & 0.00 & 0.92 & 1.00 & 1.18 \\
\hline 3 & -0.03 & 0.03 & 0.11 & -0.07 & 0.05 & 0.21 & -0.01 & 0.01 & 0.03 & 0.94 & 1.01 & 1.18 \\
\hline 4 & -0.03 & 0.02 & 0.10 & -0.06 & 0.05 & 0.19 & -0.01 & 0.01 & 0.05 & 0.95 & 1.01 & 1.18 \\
\hline 5 & -0.03 & 0.02 & 0.09 & -0.07 & 0.05 & 0.19 & -0.01 & 0.01 & 0.06 & 0.94 & 1.01 & 1.18 \\
\hline 6 & -0.03 & 0.02 & 0.09 & -0.07 & 0.05 & 0.20 & -0.01 & 0.02 & 0.07 & 0.94 & 1.01 & 1.18 \\
\hline 7 & -0.03 & 0.02 & 0.09 & -0.07 & 0.05 & 0.20 & -0.01 & 0.02 & 0.08 & 0.94 & 1.01 & 1.18 \\
\hline 8 & -0.03 & 0.02 & 0.09 & -0.07 & 0.05 & 0.19 & -0.02 & 0.02 & 0.08 & 0.94 & 1.01 & 1.18 \\
\hline 9 & -0.03 & 0.02 & 0.09 & -0.07 & 0.05 & 0.19 & -0.02 & 0.02 & 0.08 & 0.94 & 1.01 & 1.18 \\
\hline 10 & -0.03 & 0.02 & 0.09 & -0.07 & 0.05 & 0.19 & -0.02 & 0.02 & 0.09 & 0.94 & 1.01 & 1.18 \\
\hline 11 & -0.03 & 0.02 & 0.09 & -0.07 & 0.05 & 0.19 & -0.02 & 0.03 & 0.09 & 0.94 & 1.01 & 1.18 \\
\hline 12 & -0.03 & 0.02 & 0.09 & -0.07 & 0.05 & 0.19 & -0.02 & 0.03 & 0.10 & 0.94 & 1.01 & 1.18 \\
\hline 13 & -0.03 & 0.02 & 0.09 & -0.07 & 0.05 & 0.19 & -0.01 & 0.03 & 0.10 & 0.94 & 1.01 & 1.18 \\
\hline 14 & -0.03 & 0.02 & 0.09 & -0.07 & 0.05 & 0.19 & -0.02 & 0.03 & 0.10 & 0.94 & 1.01 & 1.18 \\
\hline 15 & -0.03 & 0.02 & 0.09 & -0.07 & 0.05 & 0.19 & -0.02 & 0.03 & 0.10 & 0.94 & 1.01 & 1.18 \\
\hline 16 & -0.03 & 0.02 & 0.09 & -0.07 & 0.05 & 0.19 & -0.02 & 0.03 & 0.10 & 0.94 & 1.01 & 1.18 \\
\hline 17 & -0.03 & 0.02 & 0.09 & -0.07 & 0.05 & 0.19 & -0.02 & 0.03 & 0.10 & 0.94 & 1.01 & 1.18 \\
\hline 18 & -0.03 & 0.02 & 0.09 & -0.07 & 0.05 & 0.19 & -0.02 & 0.03 & 0.10 & 0.94 & 1.01 & 1.18 \\
\hline 19 & -0.03 & 0.02 & 0.09 & -0.07 & 0.05 & 0.19 & -0.02 & 0.03 & 0.10 & 0.94 & 1.01 & 1.18 \\
\hline 20 & -0.03 & 0.02 & 0.09 & -0.07 & 0.05 & 0.19 & -0.02 & 0.03 & 0.10 & 0.94 & 1.01 & 1.18 \\
\hline & $0 . * 18$ & Re &
\end{tabular}

Notes: $(*)$ Response functions of natural logarithms of each variable. LB and UB represents the lower and upper Bootstrap Bounds at 70\% confidence level, respectively.

Results can be summarized as follows:

1. The responses are positive and differ from one type of machinery to another. A permanent increase in the level of every capital stock type leads to a permanent increase in the level of output, employment and complementary capital, which varies for every machinery capital stock type receiving the shock.

2. The elasticity is not constant over time though in the fifth period long run output and labour elasticity is attained in every type of machinery investment.

3. Output responds with a lag of one year to a shock in agricultural, farmer and fishing machinery. A shock for other type of machinery capital stock produces contemporaneous effects on output.

4. Employment reacts more quickly than output, it does it instantaneously. 
5. Spill-over effects are found. Long run output elasticity of the aggregated machinery, $0.17(0.3 / 1.75)$ is lower than the computed sum of agricultural, fishing and farmer machinery, 0.03 (0.03/1), metal machinery, 0.15 (0.27/1.77) and other machinery and software, 0.02 (0.02/1.01). Thus, long run labour elasticity of the aggregated machinery, 0.36 (0.63/1.75) is lower than the computed sum of agricultural, fishing and farmer machinery, 0.05 (0.05/1), metal machinery, $0.33(0.59 / 1.77)$ and other machinery and software, 0.05 (0.05/1.01).

6. Effects on complementary capital are found only in the investment of other machinery and software and they increase along time which stands for the necessity of machinery adapted to Research and Development made.

7. Effects on production and employment have also feedback effects on each capital. Those elasticity of production and employment are achieved regarding the level of the capital that it has been studied reaches more than 0.75 percentage points over the initial level when aggregated capital is studied and 0.77 percentage points when metal machinery is isolated. Other machinery and software present a lower equilibrium level. That is, without any feedbacks, the equilibrium level should be just one percentage point over the initial one; however, in some cases its actual estimated equilibrium level is 0.77 percentage points over that i.e. metal machinery. No feedback effects are found when agricultural, farmer and fishing machinery is aisled.

All these figures suggest that the increase of one Euro in GDP could be produced in two periods either by the investment of €0.29 in agricultural, farmer and fishing machinery, $€ 1.52$ in metal machinery or $€_{3.14}$ in other machinery and software (Table 5). The amount of money needed to increase in one Euro GDP has been computed as the inverse of effect of the elasticity on GDP divided by the effect of the elasticity on each type of capital for every year (feedback effect), both in constant Euro base 2000. The elasticity has been computed dividing the SRFs by the effect on the capital, the feedback effect. The inverse of the amount of money needed to increase GDP in one Euro is the amount of money in which GDP increases when one Euro base 2000 is invested in each capital. 
Effects on Labour and GDP of the CAP 2013 reform though investment in agricultural machinery: Spanish case

Table 5 Amount of money needed to increase GDP in one Euro (both base 2000)

\begin{tabular}{lllll} 
& Aggregated & Agricultural, farmer and fishing & metal & non-specialized and software \\
\hline 1 & $€ 0.78$ & - & $€ 0.64$ & $€ 3.14$ \\
\hline 2 & $€ 1.62$ & $€ 0.29$ & $€ 1.52$ & $€ 3.14$ \\
\hline 3 & $€ 1.95$ & $€ 0.19$ & $€ 1.84$ & $€ 1.06$ \\
\hline 4 & $€ \mathbf{2 . 2 4}$ & $€ \mathbf{0 . 1 9}$ & $€ \mathbf{~ 2 . 1 2}$ & $€ \mathbf{~ 1 . 5 8}$ \\
\hline 8 & $€ 2.50$ & $€ 0.19$ & $€ 2.56$ & $€ 1.58$ \\
\hline 20 & $€ 2.50$ & $€ 0.19$ & $€ 2.56$ & $€ 1.58$ \\
\hline
\end{tabular}

Note: It has been computed as the inverse of effect of the elasticity on GDP in every year divided by the effect of the elasticity on each type of capital in every year (feedback effect), both in constant Euro base 2000. The elasticity has been computed dividing the SRFs by the effect on each capital, the feedback effect.

Following the same calculations (Figure 1), the inverse of the amount of money needed to increase net employment in one employee multiplied by $€ 100,000$ gives the increase in net employment produced by an investment of $€ 100,000$ (base 2000). These figures show that an investment in any kind of machinery increases net employment during the first periods much more than in the following ones, so investment in machinery in Spain is not saturated. After 8 periods investment in agricultural fishing and farmer machinery increases net employment in 22.39 employees per €100,000 (base 2000) while metal machinery it does it in 4.06 and other machinery and software in 2.19. 


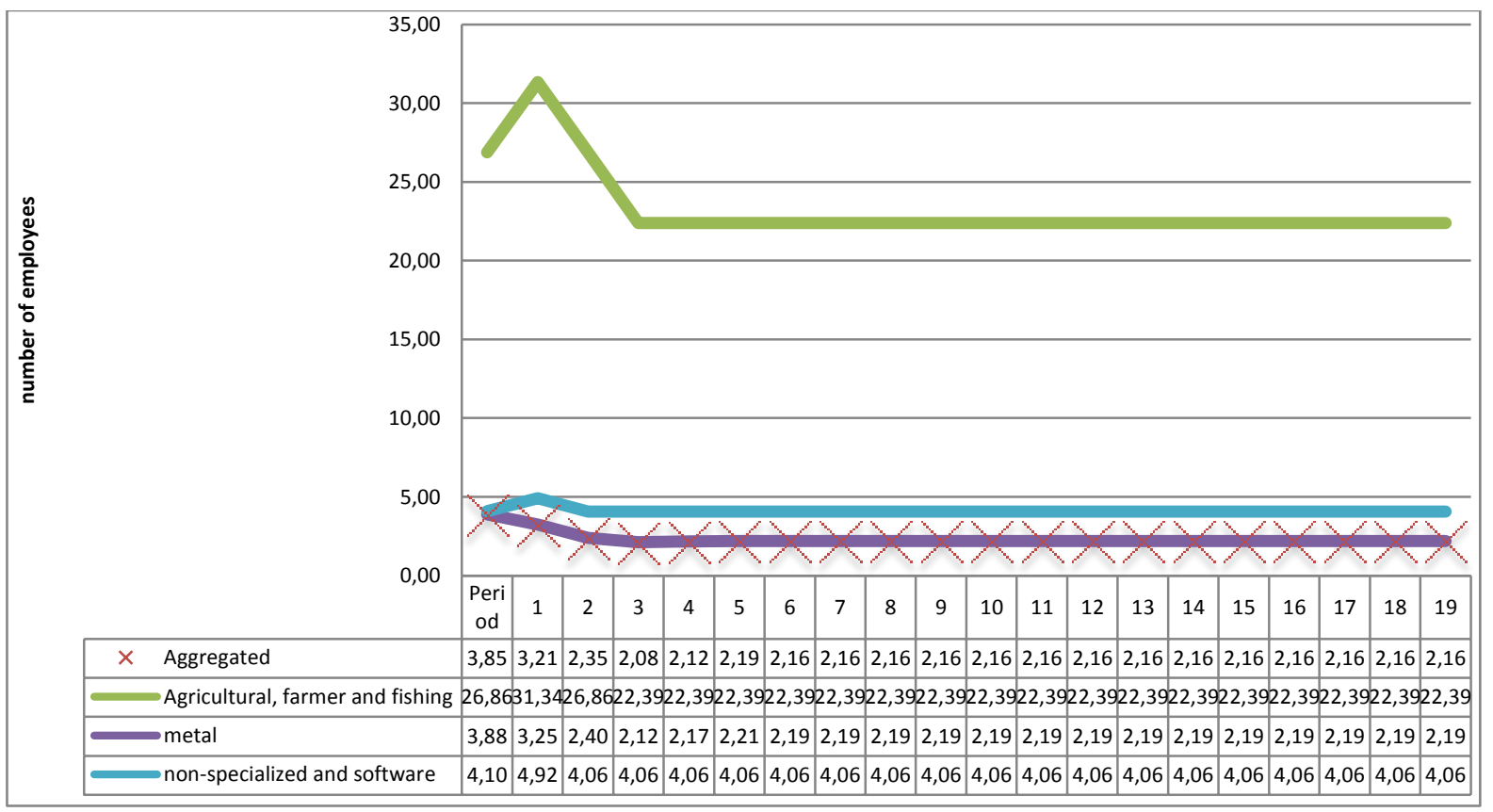

Figure 1 Net employment increase per investment of $€ 100,000$ (base 2000) in different types of machinery capital stock

\section{Theoretical Framework}

The framework used by Flores et al (1998) is adapted to the present problem as it was shown in Cosculluela and Flores (2012). The vector of relevant variables in this research is $\mathrm{W}_{\mathrm{t}}=\left(Y_{t}, L_{t}, K_{i_{t}}, \bar{K}_{i_{t}}\right)^{\prime}$, all referring to the Spanish economy. Where: $Y_{t}$ : is the Gross Domestic Product (GDP) $L_{t}$ : Total Net Employment $K_{i_{t}}$ : Different Capital Stock types, $i=4-4 \cdot 3$, accordingly to BBVA-IVIE second level classification and the four aggregated capitals. $\bar{K}_{i_{t}}$ : Complementary Capital Stock, computed as the difference between the Total Capital Stock and the studied Capital Stock type in each case.

The vector of lowercase variables $\mathrm{w}_{\mathrm{t}}=\left(y_{t}, l_{t}, \bar{k}_{i_{t}}, k_{i_{t}}\right)^{\prime}$ isolating each type of capital represents the vector of first-differenced logged variables of $\mathrm{W}_{\mathrm{t}}$. As it is shown later in this paper, $w_{t}$ it is a vector of integrated variables of order $1, I(1)$ variables. The objective is to estimate the IRFs of $y_{t}$ and $l_{t}$ to a permanent unitary shock in $k_{i_{t}}$ and by adding up the IRFs the SRFs are computed.

Those IRFs can be obtained from the dynamic structural equations set, represented in compact notation, by: 
Effects on Labour and GDP of the CAP 2013 reform though investment in agricultural machinery: Spanish case

$$
\Pi^{*}{ }_{\mathrm{w}}(\mathrm{B}) \mathrm{w}_{\mathrm{t}}=\mathrm{a}_{\mathrm{t}}^{*}
$$

where:

- $\quad \Pi^{*}{ }_{\mathrm{w}}(\mathrm{B})$ is a polynomial matrix ${ }^{2}$ in $\mathrm{B}$, the lag operator:

$$
\Pi^{*}{ }_{\mathrm{w}}(\mathrm{B})=\Pi_{0, \mathrm{w}}^{*}-\Pi_{1, \mathrm{w}}^{*} \mathrm{~B}-\Pi_{2, \mathrm{w}}^{*} \mathrm{~B}^{2}-\cdots
$$

Whose elements are $(4 \times 4)$ coefficients matrices.

- $\mathrm{a}_{\mathrm{t}}^{*}$ is $\mathrm{a}(4 \times 1)$ vector of structural shocks, which follows a white-noise vector process, with a diagonal contemporaneous covariance matrix $\Sigma^{*}$.

Alternatively, and assuming invertibility, (1) can be expressed as:

$$
\mathrm{w}_{\mathrm{t}}=\psi(B) \mathrm{a}_{\mathrm{t}}^{*}
$$

where:

- $\psi(B)=\left(\Pi^{*}{ }_{w}(B)\right)^{-1}=\psi_{0}+\psi_{1} B+\psi_{2} B^{2}+\cdots$

With each $\psi_{\mathrm{j}}$ being a $(4 \times 4)$ coefficients matrix.

The IRFs of $y_{t}$ to a shock in $k_{i_{t}}$ would be given by the sequence of coefficients, in position $(1,4)$ of $\psi_{0}, \psi_{1}, \Psi_{2}, \ldots$ matrices. Thus, the IRFs of $l_{t}$ to a shock in $k_{i_{t}}$ would be represented by the position $(2,4)$ in the sequence of matrices $\psi_{0}, \psi_{1}, \Psi_{2}, \ldots$.

To estimate $\psi(B)$ in a consistent manner, the exact identification of $\Pi_{0, w}^{*}$ is needed. That is, it is necessary to be able to pass, biunovocally, from (1) to (3):

$$
\Pi_{w}(B) w_{t}=a_{t}
$$

where:

- $\Pi_{\mathrm{w}}(\mathrm{B})=\left(\Pi_{0, \mathrm{w}}^{*}\right)^{-1} \Pi_{\mathrm{w}}^{*}(\mathrm{~B})$

\footnotetext{
${ }^{2}$ The roots of the determinant of $\Pi^{*}{ }_{w}(B)$ must lie on or outside the unit circle.
} 
- $\mathrm{a}_{\mathrm{t}}=\left(\Pi_{0, \mathrm{w}}^{*}\right)^{-1} \mathrm{a}_{\mathrm{t}}^{*}$

with:

$$
\mathrm{E}\left(\mathrm{a}_{\mathrm{t}}, \mathrm{a}_{\mathrm{t}}^{\prime}\right)=\Sigma=\left(\Pi_{0, \mathrm{w}}^{*}\right)^{-1} \Sigma^{*}\left(\Pi_{0, \mathrm{w}}^{*^{\prime}}\right)^{-1}
$$

That is, $\Pi^{*}{ }_{\mathrm{w}}(\mathrm{B})$ can be estimated if there is only one matrix which diagonalizes $\Sigma$, that is $\Pi_{0, w}^{*}$.

Equation (3) is the non-stationary VARMA process for the I(1) vector of variables in $\mathrm{w}_{\mathrm{t}}$, which can be approximated by a finite $\operatorname{VAR}(\mathrm{p})$ process. The process (3) can be estimated directly from the data set, using standard techniques.

The matrix $\Pi_{0, \mathrm{w}}^{*}$ can be estimated from the estimation of $\Sigma$ as long as there are enough restrictions on it. Once $\Pi_{0, \mathrm{w}}^{*}$ has been estimated, $\widehat{\Pi}_{\mathrm{w}}^{*}(\mathrm{~B})$ can be obtained from:

$$
\widehat{\Pi}_{\mathrm{w}}^{*}(\mathrm{~B})=\widehat{\Pi}_{0, \mathrm{w}}^{*} \widehat{\Pi}_{\mathrm{w}}(\mathrm{B})
$$

Finally, the IRFs can be obtained from:

$$
\widehat{\Psi}(\mathrm{B})=\left[\widehat{\Pi}_{\mathrm{W}}^{*}(\mathrm{~B})\right]^{-1}
$$

The key in order to find the responses of $y_{t}$ and $l_{t}$ to a shock in $k_{i_{t}}$ consists in introducing enough restrictions in $\Pi_{0, w}^{*}$ for this matrix to become the particular matrix able to diagonalize $\Sigma$.

Each coefficient in $\Pi_{0, w}^{*}$ represents the instantaneous structural response of a variable to a shock in other variable included in $w_{t}$. However, for our purpose, the complete identification of $\Pi_{0, \omega}^{*}$ it is not necessary, that is, it is not necessary to identify every element in $\mathrm{a}_{\mathrm{t}}^{*}$.

In $\mathrm{w}_{\mathrm{t}}$ it can be distinguished two types of variables, vector $\mathrm{z}_{\mathrm{t}}=\left(y_{t}, l_{t}\right)^{\prime}$ and vector $\mathrm{k}_{\mathrm{t}}=\left(k_{i_{t}}, \bar{k}_{i_{t}}\right)^{\prime}$. The vector $\mathrm{k}_{\mathrm{t}}$ is made on variables more rigid than variables in $\mathrm{z}_{\mathrm{t}}$; that is, $z_{t}$ variables responses are faster than responses of $k_{t}$. It seems reasonable to think 
Effects on Labour and GDP of the CAP 2013 reform though investment in agricultural machinery: Spanish case

that a shock in $\mathrm{k}_{\mathrm{t}}$ (in period $\mathrm{t}$ ) would have both instantaneous and lagged effects on the variables in $\mathrm{z}_{\mathrm{t}}$. However, a shock in period $\mathrm{t}$ in any variable of $\mathrm{z}_{\mathrm{t}}$ would only cause lagged responses of $\mathrm{k}_{\mathrm{t}}$ variables. It means that $\mathrm{k}_{\mathrm{t}}$ variables need time to react to changes in $y_{t}$ or $l_{t}$.

Thus, $\mathrm{k}_{\mathrm{t}}$ levels are determined by past values of $\mathrm{z}_{\mathrm{t}}$, while $\mathrm{z}_{\mathrm{t}}$ values are determined by past and present values of $\mathrm{k}_{\mathrm{t}}$.

Formally, the behaviour of vectors $\mathrm{z}_{\mathrm{t}}$ and $\mathrm{k}_{\mathrm{t}}$ can be represented as:

$$
\begin{gathered}
\mathrm{z}_{\mathrm{t}}=\mathrm{v}_{\mathrm{z}}(\mathrm{B}) \mathrm{k}_{\mathrm{t}}+\mathrm{N}_{\mathrm{z}_{\mathrm{t}}} \\
\pi_{\mathrm{z}}(\mathrm{B}) \mathrm{N}_{\mathrm{z}_{\mathrm{t}}}=\alpha_{\mathrm{z}_{\mathrm{t}}} \\
\mathrm{k}_{\mathrm{t}}=\mathrm{v}_{\mathrm{k}}(\mathrm{B}) \mathrm{z}_{\mathrm{t}}+\mathrm{N}_{\mathrm{k}_{\mathrm{t}}} \\
\pi_{\mathrm{k}}(\mathrm{B}) \mathrm{N}_{\mathrm{k}_{\mathrm{t}}}=\alpha_{\mathrm{k}_{\mathrm{t}}}
\end{gathered}
$$

Where $v_{\mathrm{z}}(B)$ and $\mathrm{v}_{\mathrm{k}}(\mathrm{B})$ are $(2 \times 2)$ matrices of stable transfer functions:

$$
\mathrm{v}_{\mathrm{z}}(\mathrm{B})=\left(\begin{array}{cc}
\mathrm{v}_{\bar{k}_{\bar{k}_{i t}}}(\mathrm{~B}) & \mathrm{v}_{y_{k_{i_{t}}}}(\mathrm{~B}) \\
\mathrm{v}_{\bar{k}_{\bar{k}_{t}}}(\mathrm{~B}) & \mathrm{v}_{l_{k_{i_{t}}}}(\mathrm{~B})
\end{array}\right) \text { and } \mathrm{v}_{\mathrm{K}}(\mathrm{B})=\left(\begin{array}{cc}
\mathrm{v}_{\bar{k}_{i_{y_{t}}}}(\mathrm{~B}) & \mathrm{v}_{\bar{k}_{i_{l}}}(\mathrm{~B}) \\
\mathrm{v}_{k_{i_{y_{t}}}}(\mathrm{~B}) & \mathrm{v}_{k_{i_{l_{t}}}}(\mathrm{~B})
\end{array}\right)
$$

Each transfer function in $v_{\mathrm{z}}(\mathrm{B})$ represents the unidirectional response function of each variable $y_{t}$ and $l_{t}$ to shocks in $\mathrm{k}_{\mathrm{t}}$.

At the same time, $\mathrm{k}_{\mathrm{t}}$ variables have different yield. It seems reasonable that other than complementary infrastructures $\bar{k}_{i_{t}}$ take longer to react than the capital infrastructure $k_{i_{t}}$ to be studied.

Each capital stock $k_{i_{t}}$ will react instantaneously (in the same year) to changes in other infrastructures $\bar{k}_{i_{t}}$ and will continue reacting to those changes over several years. However, other infrastructures $\bar{k}_{i_{t}}$ will only show lagged reactions to changes in the isolated capital stock, i.e. they would not react in the same year. Thus, shocks in highways, railways or any other capital stock will produce changes in other infrastructures such as, houses, machinery etc. But those changes will take place from 
the second year onwards, not in the same year in which the shock in each type of capital stock is produced.

It is important to note that the empirical analysis will show significant contemporaneous correlations between these variables in some of the capital types studied, and therefore, this assumption it is totally necessary.

This idea in mathematic notation can be represented as:

$$
\begin{gathered}
\mathrm{k}_{\mathrm{t}}=\mathrm{v}_{\mathrm{k}}(\mathrm{B}) \mathrm{z}_{\mathrm{t}}+\mathrm{N}_{\mathrm{k}_{\mathrm{t}}} \\
\pi_{\mathrm{k}}(\mathrm{B}) \mathrm{N}_{\mathrm{k}_{\mathrm{t}}}=\alpha_{\mathrm{k}_{\mathrm{t}}}
\end{gathered}
$$

with

$$
\mathrm{E}\left(\alpha_{\mathrm{k}_{\mathrm{t}}} \alpha_{\mathrm{k}_{\mathrm{t}}}^{\prime}\right)=\Sigma_{\mathrm{k}}=\mathrm{P}_{\mathrm{k}} \Sigma_{\mathrm{k}}^{*} \mathrm{P}_{\mathrm{k}}^{\prime}
$$

Where $P_{K}=\left(\begin{array}{cc}1 & 0 \\ -\beta & 1\end{array}\right)$ is the diagonalization matrix for $\Sigma_{k}$ and $\beta$ is the slope in regression (13).

$$
\alpha_{\mathrm{k}_{\mathrm{t}}}=\beta \alpha_{\overline{\mathrm{k}}_{\mathrm{t}}}+\alpha_{\mathrm{k}_{\mathrm{t}}}^{*}
$$

Taking into account this assumption (10) would be:

$$
\mathrm{P}_{\mathrm{k}} \Pi_{\mathrm{k}}(\mathrm{B}) \mathrm{k}_{\mathrm{t}}=\mathrm{P}_{\mathrm{k}} \Pi_{\mathrm{k}}(\mathrm{B}) v_{\mathrm{k}}(\mathrm{B}) \mathrm{z}_{\mathrm{t}}+\mathrm{P}_{\mathrm{k}} \alpha_{\mathrm{k}_{\mathrm{t}}}
$$

or

$$
\mathrm{P}_{\mathrm{k}} \Pi_{\mathrm{k}}(\mathrm{B}) \mathrm{k}_{\mathrm{t}}=\mathrm{P}_{\mathrm{k}} \Pi_{\mathrm{k}}(\mathrm{B}) v_{\mathrm{k}}(\mathrm{B}) \mathrm{z}_{\mathrm{t}}+\alpha_{\mathrm{k}_{\mathrm{t}}}^{+}
$$

with

$$
\mathrm{E}\left(\alpha_{\mathrm{k}_{\mathrm{t}}}^{+}, \alpha_{\mathrm{k}_{\mathrm{t}}}^{+\prime}\right)=\Sigma_{\mathrm{k}}^{+}
$$


Effects on Labour and GDP of the CAP 2013 reform though investment in agricultural machinery: Spanish case

diagonal.

Equations (9) and (15) in compact notation would be:

$$
\left[\begin{array}{cc}
\Pi_{\mathrm{z}}(\mathrm{B}) & -\Pi_{\mathrm{z}}(\mathrm{B}) v_{\mathrm{z}}(\mathrm{B}) \\
-\mathrm{P}_{\mathrm{k}} \Pi_{\mathrm{k}}(\mathrm{B}) v_{\mathrm{k}}(\mathrm{B}) & \mathrm{P}_{\mathrm{k}} \Pi_{\mathrm{k}}(\mathrm{B})
\end{array}\right] \times\left[\begin{array}{c}
\mathrm{z}_{\mathrm{t}} \\
\mathrm{k}_{\mathrm{t}}
\end{array}\right]=\left(\begin{array}{c}
\alpha_{\mathrm{z}_{\mathrm{t}}} \\
\alpha_{\mathrm{k}_{\mathrm{t}}}^{+}
\end{array}\right)
$$

with

$$
\mathrm{E}\left[\left(\begin{array}{c}
\alpha_{\mathrm{z}_{\mathrm{t}}} \\
\alpha_{\mathrm{k}_{\mathrm{t}}}^{+}
\end{array}\right)\left(\begin{array}{ll}
\alpha_{\mathrm{z}_{\mathrm{t}}}^{\prime} & \alpha_{\mathrm{k}_{\mathrm{t}}}^{+\prime}
\end{array}\right)^{\prime}\right]=\left[\begin{array}{cc}
\Sigma_{\mathrm{z}} & 0 \\
0 & \Sigma_{\mathrm{k}}^{+}
\end{array}\right]
$$

This model is similar to (1), the difference between them is the dependence of the variables in $\alpha_{z_{\mathrm{t}}}$, that is the non diagonal character of $\Sigma_{z}$. However it will be possible to estimate the response functions of each one of the elements of $z_{t}$ to a shock in $k_{i_{t}}$. Model (16)-(17) in compact notation would be:

$$
\Pi^{+}(\mathrm{B}) \mathrm{w}_{\mathrm{t}}=\alpha_{\mathrm{t}}^{+}
$$

with

$$
\mathrm{E}\left(\alpha_{\mathrm{t}}^{+} \alpha_{\mathrm{t}}^{+^{\prime}}\right)=\Sigma^{+}
$$

block diagonal.

Since $\Pi^{+}(0)=\left[\begin{array}{cc}\mathrm{I} & -v_{\mathrm{z} 0} \\ 0 & \mathrm{P}_{\mathrm{k}}\end{array}\right] \neq \mathrm{I}$, the stochastic multivariate model (16) is not normalized in the sense of Alavi (Jenkins and Alavi, 1981). However, it can be normalized by pre-multiplying (18) by $\left[\Pi^{+}(0)\right]^{-1}$ :

$$
\left[\Pi^{+}(0)\right]^{-1} \Pi^{+}(\mathrm{B}) \mathrm{w}_{\mathrm{t}}=\left[\Pi^{+}(0)\right]^{-1} \alpha_{\mathrm{t}}^{+}
$$


where (20) is equal to (3) with

$$
\begin{aligned}
\Pi(B) & =\left[\Pi^{+}(0)\right]^{-1} \Pi^{+}(B) \\
a_{t} & =\left[\Pi^{+}(0)\right]^{-1} \alpha_{t}^{+}
\end{aligned}
$$

Estimating (3) and its corresponding instant covariance matrix, it allows estimating in a consistent manner all the parameters in (18) and $(19)^{3}$, that is, $\left[\Pi^{+}(B)\right]$ and $\Sigma^{+}$ which are similar to model $(1)$; and from them, the IRFs. Positions $(1,4)$ and $(2,4)$ of the polynomial elements in (22) will give the response functions of $y_{t}$ and $l_{t}$, respectively.

$$
\mathrm{w}_{\mathrm{t}}=\Psi^{+}(\mathrm{B}) \alpha_{\mathrm{t}}^{+}
$$

with

$$
\Psi^{+}(\mathrm{B})=\left[\Pi^{+}(\mathrm{B})\right]^{-1}=\Psi_{0}^{+}+\Psi_{1}^{+} \mathrm{B}+\Psi_{2}^{+} \mathrm{B}^{2}+\cdots
$$

In the following section, expressions (20) and (23) are estimated.

\section{Estimation of the Theoretical Model.}

\section{The Data:}

It has been used yearly data of the Spanish economy for the period 1977/2005:

$Y_{t}$ : Gross Domestic Product (GDP) obtained from the World Bank. Thousands of Euros, base year 2000.

$L_{t}$ : Total employment 4 , measured in thousands of workers obtained from the Spanish "Encuesta de Población Activa, EPA" published by the Spanish Statistical Institute (INE, 2006).

$K_{i_{t}}$ : Capital Stock Data computed by IVIE and published by BBVA foundation (Mas et $a l$, 2007), where $i=4-4.3$ accordingly to BBVA-IVIE second level classification.

$\bar{K}_{i_{t}}$ : Capital Stock Data computed by IVIE and published by BBVA foundation (Mas et $a l$, 2007), excluding the isolated Capital Stock $K_{i_{t}}$.

All capital stock series are measured in thousands of Euros with base year 2000.

\footnotetext{
${ }^{3}$ All mathematical details have been taken to the appendix.

4 Ceuta and Melilla employment is not computed to avoid missing data in the first periods of time.
} 
Effects on Labour and GDP of the CAP 2013 reform though investment in agricultural machinery: Spanish case

Univariate Analysis. The values of the augmented Dickey-Fuller (ADF) test for a unit root in first and second differenced series show that all variables are I(2). The absence of MA terms from the Autoregressive Integrated Moving Average (ARIMA) univariate models suggests that none of the series seems to be over differenced. No important outliers have been found; therefore no intervention analysis is needed5.

\section{Cointegration. Johansen $(1988,1991)$ and Engel and Granger (Granger and} Engel, 1987) methods were used to study the presence of cointegration relationships among the set of I(1) variables $\left(y_{t}, l_{t}, \bar{k}_{i_{t}}, k_{i_{t}}\right)$.

Results suggest that there is one cointegration equation $\xi_{1_{\mathrm{t}}}$ (Figure 2), which involves production and employment growth rates isolating every type of capital stock ${ }^{6}$.

$$
\xi_{1 t}=y_{t}-0.47_{(0.05)} l_{t}-0.02_{(0.001)}
$$
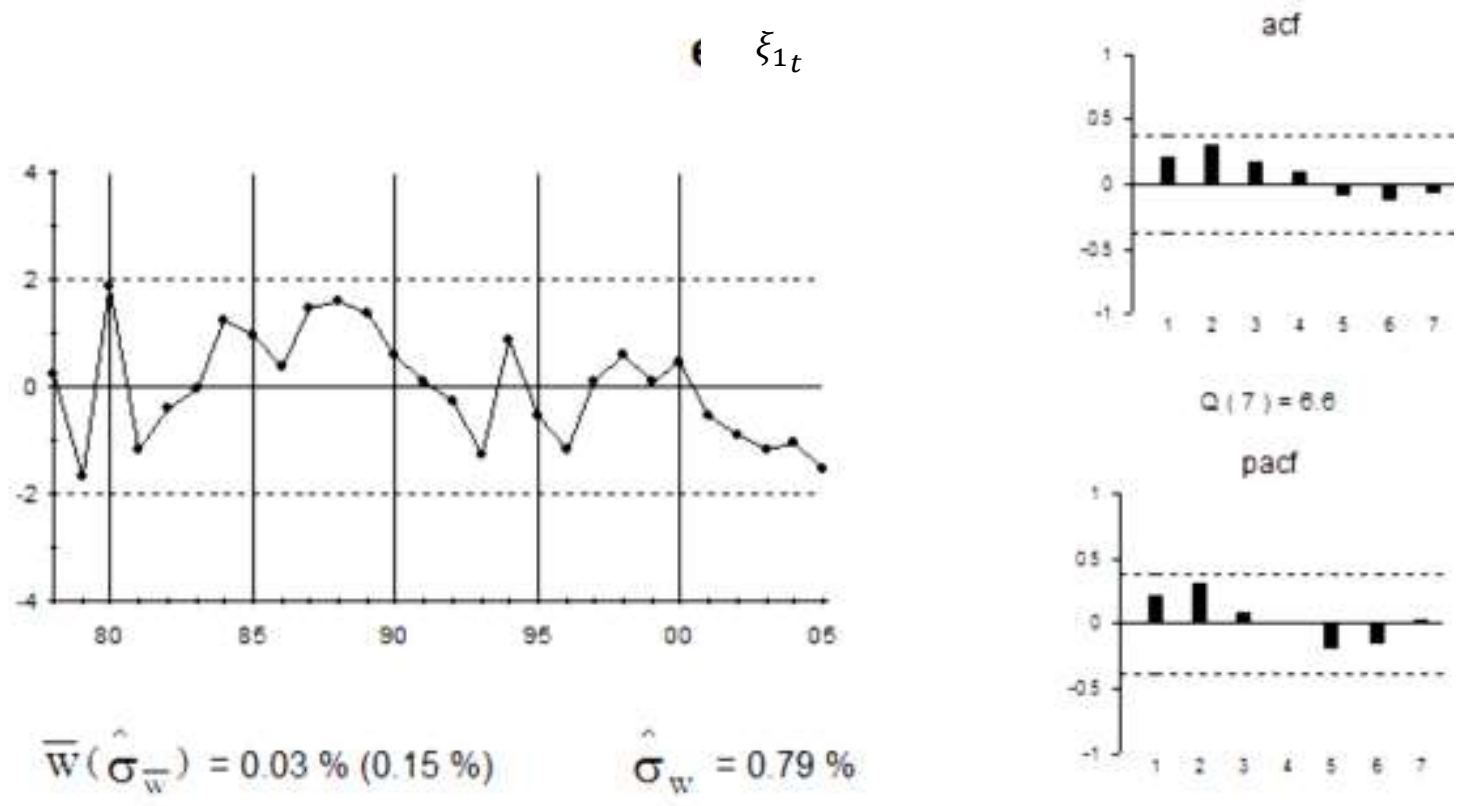

Figure 2 Cointegration Equation $\xi_{1 t}$

\footnotetext{
5 Under request all ARIMA univariate analisys, ADF test can be provided Cosculluela.c@gmail.com.

${ }^{6}$ All regressions including all the variables and constant term have been estimated. The ADF test indicates that for every $\mathrm{w}$ vector isolating every type of capital stock, the residuals of the regression of $y_{t}$ on $l_{t}, k_{i_{t}}$ and $\bar{k}_{i_{t}}$ are I(0) accordingly to Phillips and Oulliaris (1990) critical values (95\% critical value, -4.11). There are also I(o) when each capital series is not considered in the regression (95\% critical value, -3.77) or when both of them are excluded (95\% critical value, -3.37). Thus, when $l_{t}$ is not included in the regression of $y_{t}$ on each capital series or on both of them, ADF test indicates that residuals are I(1). ADF test indicates that the residuals of the regressions of $l_{t}, k_{i_{t}}$ and $\bar{k}_{i_{t}}$ on the other variables in each set of variables that isolates every type of capital stock series are I(1), except when airport infrastructures is the isolated capital.
} 
Cointegration equation $\xi_{1 \mathrm{t}}$ can be interpreted as a stable or equilibrium positive relationship between production and employment growth rates, where the disequilibrium in each period $t$ is measured by $\xi_{1}$.

\section{Estimation of the Multivariate Model:}

Akaike information criterion (AIC)7 suggest a VAR(3). VEC(2), on twice differenced variables, has been jointly estimated by Generalized Least Squares (GLS). All nonsignificant parameters have been constrained to be zero. AIC applied to the residuals of the model shows that $\mathrm{a}_{\mathrm{t}}$ follows a multivariate white noise process ${ }^{8}$. From $\hat{\Sigma}$ the instant correlation matrix $\hat{\rho}$ can be computed and $\widehat{\Pi}_{0, w}^{*}$ can be estimated. $\widehat{\Pi}_{0, w}^{*}$ allows estimating (18) from (20). Pre-multiplying (20) by $\widehat{\Pi}_{0, \mathrm{w}}^{*}$ model (18) will be estimated.

Table 8 contains the resulting model (18) adjusted to data. The model is presented in

Table 8 as:

$$
\widehat{\Pi}_{\mathrm{w}}^{*}(\mathrm{~B}) \mathrm{w}_{\mathrm{t}}=\hat{\mathrm{a}}_{\mathrm{t}}^{*}
$$

\begin{tabular}{c|c|c}
\hline$\widehat{\Pi}_{\mathrm{w}}^{*}(\mathrm{~B})$ & $\mathrm{w}_{\mathrm{t}}$ & $\hat{\mathrm{a}}_{\mathrm{t}}^{*}$ \\
\hline$\left[\begin{array}{cc}\widehat{\Pi}_{\mathrm{w}_{11}}^{*}(\mathrm{~B}) & \widehat{\Pi}_{\mathrm{w}_{12}}^{*}(\mathrm{~B}) \\
\widehat{\Pi}_{\mathrm{w}_{21}}^{*}(\mathrm{~B}) & \widehat{\Pi}_{\mathrm{w}_{22}}^{*}(\mathrm{~B})\end{array}\right]$ & $\left(\begin{array}{c}y_{t} \\
l_{t} \\
\bar{k}_{i_{t}} \\
k_{i_{t}}\end{array}\right)+\left(\begin{array}{c}\mathrm{c}_{1} \\
\mathrm{c}_{2} \\
\mathrm{c}_{3} \\
\mathrm{c}_{4}\end{array}\right)$ & $\left(\begin{array}{c}\hat{\mathrm{a}}_{y_{t}}^{*} \\
\hat{\mathrm{a}}_{l_{t}}^{*} \\
\hat{\mathrm{a}}_{\bar{k}_{i t}}^{*} \\
\hat{\mathrm{a}}_{k_{i t}}^{*}\end{array}\right)$ \\
\hline
\end{tabular}

Together with their corresponding $\widehat{\Sigma}, \hat{\rho}$ and $\widehat{\Pi}_{0, \mathrm{w}}^{*}$ matrix.

Table $\mathbf{8}$ shows dynamic relations among all the variables. As it has been explained in Section II, IRFs can be obtained from the reduced form of model (18) in

Table 8. By adding up the IRFs, the corresponding SRFs are computed which will be commented in the following section. Elasticity is computed dividing the SRFs of output, employment or complementary capital by the SRFs of the capital receiving the shock.

\footnotetext{
${ }^{7}$ Diagnosis of the process is shown in the appendix III.

8 The diagnosis of all the estimated models can be provided under request Cosculluela.c@gmail.com
} 


\section{Conclusions.}

It is known that the effects on the economy of the investment in physical capital stock vary from one type of capital to another. However, to find disaggregated econometric estimations of its importance is difficult. This paper deals with this problem and proposes a general conceptual framework for estimating the responses of output and labour to a permanent, one percentage point increase in the level of agricultural, fishing and farming machinery capital stock.

This conceptual framework has the advantage that does not constrains the statistical properties of the time series used, as well as allows for estimating the structural response functions required in this case. One assumption has been necessary, related with the causal interpretation of possible existing contemporaneous correlations among two sets of variables: output plus labour on one side, and agricultural, fishing and farming machinery capital stock plus complementary capital stock on the other. It has been assumed that both, output and labour can react instantaneously to a shock in any variable of the second set, but agricultural, fishing and farming machinery capital stock cannot react instantaneously to a shock neither in output or labour. None lagged reaction is constrained on a priori grounds. This only assumption is enough for identifying the structural response functions of output and labour.

Using data for the Spanish economy (1977/05) and standard vector error correction models methodology it has been possible to estimate the differences in between the economic effects produced by different types of physical capital investment providing a general macroeconomic policy instrument to evaluate the increase in output and labour produced by physical investment.

An investment in agricultural, fishing and farming machinery produces the highest instant effects on employment. After 8 periods increases 22.39 employees net employment per €100,000 (base 2000) invested while metal machinery it does it in 4.06 and other machinery and software in 2.19.

GDP reacts with a lag of one period. The lowest investment needed to increase GDP in $€ 1$ in two periods across the investment in machinery is of $€ 0.29$ in agricultural, farmer and fishing machinery. 
Spill-over effects have been found. Effects on complementary capital are found only in the investment of other machinery and software and they increase along time which stands for the necessity of machinery adapted to Research and Development made.

The effects -on labour and production- of different machinery investment at different terms has been studied. Those results conclude that the impact of the 2013 negotiation of the CAP founds, which represent almost $47 \%$ of the $€ 864.3$ billion EUs budget for the period 2007-2013, the largest single expenditure item has very important effects on net employment and GDP Spanish growth 


\section{Referencias Bibliográficas}

Aaron H. (1990) Discussion On Why Is Infrastructure Important? In Is There A Shortfall In Public Capital Investment?, in Conference Series, A. Mundell, ed., vol. 34, Federal Reserve Bank of Boston.

Aschauer D.A. (1989a) Does public capital crowd out private capital? Journal of Monetary Economics, 24,171-188.

Aschauer D.A. (1989b) Is public expenditure productive? Journal of Monetary Economics, 23,177-200.

Berndt, E. and Hansson, B. (1992) Measuring The Contribution Of Public Infrastructure Capital In Sweden, The Scandinavian Journal of Economics, 94, 151-168.

Cantos P.,Gumbau-Albert M. and Maudos J. (2005) Transport infrastructures and regional growth: Evidence of the Spanish case, Transport Reviews, (25)1, 25-50

Cosculluela-Martínez and Flores, R. (2012) Housing investment in Spain: Has it been the main engine of growth? Applied Economics, DOI 10.1080/00036846.2011.639740.

Cullison W. E. (1993) Public Investment and Economic Growth, Economic Quarterly, 19-34. Avaliable in http://ideas.repec.org/a/fip/fedreq/y1993ifallp19-34.html.

Dickey D. A. and Fuller W. A. (1979), Distribution of the Estimators for Autoregressive Time Series with Unit Root, Journal of the American Statistical Association, 74, pp. 427-431.

Dickey D. A. and Fuller W. A (1981), Likelihood Ratio Statistics for Autoregressive Time Series with a Unit Root, Econometrica, 49, 1057-72.

Eberts R. (2007) Highway Infraestructure: Policy Issues For Regions, Federal Reserve Bank of Chicago, 1-16.

Eisner R. (1991) Infrastructure And Regional Economic Performance: Comment, New England Economic Review, 67, 297-308. 
Evans P. and G. Karras G. (1994) Are Government Activities Productive? Evidence From A Panel Of The U.S. States, The Review of Economics and Statistics, LXXVI, 1-11.

Flores, R., Gracia, M., and Perez, T. (1998) Public capital stock and economic growth: an analysis of the Spanish economy, Applied Economics, 30, 985-994.

García-Milá T. and McGuire T. (1994) The Contribution Of Publicity Provides Inputs To States Economies, Regional Science and Urban Economics, 22, 229-41.

Gorostiaga A. (1999) ¿Cómo afectan el capital público y el capital humano al crecimiento: un análisis para las regiones españolas en el marco neoclásico, Investigaciones Económicas.

Granger, C. W. J. and Engle, R. F. (1987) Co-integration and error correction: represen $\neg$ tation, estimation and testing, Econometrica, 251-276.

Holtz-Eakin D. (1988) Private Output, Government Capital And The Infrastructure Crisis, Discussion Paper Series 394, Columbia University.

Holtz-Eakin D. (1994) Public Sector Capital And The Productivity Puzzle, The Review of Economics and Statistics, LXXVI, pp. 12-21.

Hulten C. and Schwab R. (1991a), Is There Too Little Public Capital?: Infrastructure And Economic Growth, American Enterprise Institute for Public Policy Research.

Hulten C. and Schwab R. (1991b) Public Capital Formation And The Growth Of Regional Manufacturing Industries, National Tax Journal, 121-134.

Hulten C. and Schwab R. (1993) Infrastructure Expending: Where Do We Go From Here?, National Tax Journal, 261-274.

Jenkins G.M., and Alavi, A.S. (1981) Some aspects of modelling and forecasting multivariate time series. Journal of time series analysis, 2, 1-47.

Johansen S. (1988), Statistical analysis of cointegration vectors, Journal of Economic Dynamics and Control, 12, 231-254. 
Effects on Labour and GDP of the CAP 2013 reform though investment in agricultural machinery: Spanish case

Johansen S. (1991), Estimation and hypothesis testing of cointegration vectors in gaussian vector autoregressive models, Econometrica, 59, 1551-1580.

Jorgenson D. (1991), Fragile Statistical Foundations: The Macroeconomics Of Public Infrastructure Investment, American Enterprise Institute Conference on Infrastructure Needs and Policy Options for the 1990s, Washington D.C., 4 February.

Kamps C. (2004), New Estimates Of Government Net Capital Stocks For 22 OECD Countries (1960-2001), International Monetary Fund.

Ligthart J. (2002) Public Capital And Output Growth In Portugal: An Empirical Analysis, European Review of Economics and Finance, 1, 3-30.

Lynde C. and Richmond J. (1992) The Role Of Public Capital In Production, The Review of Economics and Statistics, 74, 37-44.

Lynde C. and Richmond J. (1993) Public Capital And Total Factor Productivity, International Economic Review, 34, pp. 401-414.

Mas M. , Maudos J., Pérez F., and Uriel E. (1993), Competitividad, productividad industrial y dotaciones de capital público, Papeles de Economía Española, 144160.

Mas M. , Maudos J., Pérez F., and Uriel E. (1994) Capital público y productividad en las regiones españolas, Moneda y Crédito, 163-206.

Mas M. , Maudos J., Pérez F., and Uriel E. (1995) Infrastructures and Productivity in Spanish Regions, ch. 13 .

Mas Ivars M., Pérez García P. and Uriel Jiménez E. (2007), El stock y los servicios del capital en España y su distribución territorial, Fundación BBVA.

Munnell A. (1990), Why Has Productivity Declined? Productivity And Public Investment, New England Economic Review, 3-22.

Munnell A. (1992) Infrastructure Investment And Economic Growth, Journal of Economic Perspectives, 6, 189-198. 
Munnell A. and Cook L. (1990), How Does Public Infrastructure Affect Regional Economic Performance?, In Is There A Shortfall In Public Capital Investment? New England Economic Review, 34, Boston, Sept/Oct, Federal Reserve Bank of Boston.

Nadiri M. and Mamuneas T. (1994) The Effects Of Public Infrastructure And The R\&D Capital On The Cost Structure And Performance Of U.S. Manufacturing Industries, The Review of Economics and Statistics, LXXVI, 28-37.

Pereira, A. M. (1997). Public Investment and Private Sector Performance-International Evidence. Public Finance \& Management, 2(1): 261-277.

Pereira, A. M. (2000). Is all public capital created equal? Review of Economics and Sta $\neg$ tistics, 82 (3), 513-518, Aug.

Pereira, A. M. and Andráz, J. M. (2005). Public investment in transportation infrastructure and economic performance in Portugal, Review of Development Economics, 9, 177-96.

Pereira, A. M. and Andráz, J. M. (2010a). On the economic effects of investment in rail $\neg$ road infrastructures in Portugal, College of William and Mary, Working Papers in economics, No. 96, Universidade do Algarve, Portugal.

Pereira, A. M. and Andráz, J. M. (2010b). On the economic effects of investment in Railroad infrastructures in Portugal, The College of William and Mary, Williamsburg Working paper $\mathrm{n}^{\circ} 96$, July.

Pereira, A. M. and Flores de Frutos, R. (1999). Public Capital Accumulation and Private Sector Performance. Journal of Urban Economics, 46, 303-22.

Pereira A. M. and O. Roca Sagales O., Spillover Effects Of Public Capital Formation: Evidence From The Spanish Regions, Working Papers wpdeao210, Department of Applied Economics at Universitat Autónoma of Barcelona, Jan 2003. Available in http://ideas.repec.org/p/uab/wprdea/wpdeao210.html.

Phillips P. B. C. And Durlauf N. S. (1986), Multiple Time Series Regression With Integrated Process, Review of Economic Studies, 53, pp. 473-495. 
Effects on Labour and GDP of the CAP 2013 reform though investment in agricultural machinery: Spanish case

Phillips P. C. B. (1998) Impulse Response And Forecast Error Variance Asymptotics In Nonstationary VARs, Journal of Econometrics, 83, pp. 21-56. Available in http://ideas.repec.org/a/eee/econom/v83y1998i1-2p21-56.html.

Seitz H. (1994) Public Capital And The Demand For Private Inputs, Journal of Public Economics, 54, pp. 287-307.

Shah A. (1992) Dynamics Of Public Infrastructure, Industrial Productivity And Profitability, The Review of Economics and Statistics, LXXIV, pp. 28-36.

Tatom J. (1991) Public Capital And Private Sector Performance, Review of Federal Reserve Bank of St. Louis, 73 , pp. 3-15.

Ulrich K. (2010) Distortions to Agricultural Incentives. A Global Perspective, 1955 to 2007," Journal of Agricultural Economics, Wiley Blackwell, vol. 61(1), pp 194198.

Voss, G. M. (2002) Public And Private Investment In The United States And Canada, Economic Modeling, 19, pp. 641-64. 


\section{Appendix.}

\section{Appendix I. Data.}

Table 6 Data. Main aggregated Capital Stock

\begin{tabular}{|c|c|c|c|c|}
\hline Year & GDP & LABOUR & Total Capital Stock & 4. Machinery Capital Stock \\
\hline 1977 & 345224904.70 & 12594.38 & 1088822267 & 106511785 \\
\hline 1978 & 350275502.08 & 12398.28 & 1136945841 & 110439850 \\
\hline 1979 & 350421090.30 & 12227.50 & 1180460634 & 113157036 \\
\hline 1980 & 358160891.90 & 11894.90 & 1222594208 & 115717706 \\
\hline 1981 & 357686509.57 & 11588.38 & 1262288977 & 117394790 \\
\hline 1982 & 362144890.88 & 11481.38 & 1301460454 & 118172290 \\
\hline 1983 & 368555294.72 & 11421.70 & 1338247528 & 118587112 \\
\hline 1984 & $375132815 \cdot 36$ & 11118.90 & 1370253267 & 118620638 \\
\hline 1985 & 383841304.58 & 11004.05 & 1404863421 & 119867922 \\
\hline 1986 & 396328894.46 & 11208.80 & 1444999566 & 122616063 \\
\hline 1987 & 418313699.33 & 11749.08 & 1492914843 & 127995437 \\
\hline 1988 & 439624007.68 & 12178.80 & 1550232290 & 135704343 \\
\hline 1989 & 460844793.86 & 12602.55 & 1617434219 & 145123075 \\
\hline 1990 & 478271111.17 & 12922.25 & 1689823644 & 154017410 \\
\hline 1991 & 490447896.58 & 13025.98 & 1761930594 & 161443799 \\
\hline 1992 & 495005204.48 & 12788.80 & 1827833648 & 167572589 \\
\hline 1993 & 489899294.72 & 12259.28 & 1882300510 & 168900134 \\
\hline 1994 & 501574598.66 & 12174.13 & 1937081749 & 170172986 \\
\hline 1995 & 515405414.40 & 12478.00 & 1998114494 & 173384637 \\
\hline 1996 & 527829401.60 & 12835.03 & 2060344847 & 179502899 \\
\hline 1997 & 548234002.43 & 13307.28 & 2126970493 & 187722612 \\
\hline 1998 & 572809478.14 & 13864.85 & 2205363875 & 200835756 \\
\hline 1999 & 600008228.86 & 14648.88 & 2295656762 & 216826588 \\
\hline 2000 & 630262988.80 & 15461.83 & 2393286747 & 234745388 \\
\hline 2001 & 652600999.94 & 16100.20 & 2494650236 & 251371225 \\
\hline 2002 & 670092886.02 & 16584.08 & 2597450307 & 265820708 \\
\hline 2003 & 690183995.39 & 17248.50 & 2705711149 & 280604758 \\
\hline 2004 & 711542571.01 & 17923.15 & 2818378849 & 295740763 \\
\hline 2005 & 735924322.30 & 18925.18 & 2943208569 & 314828715 \\
\hline 2006 & 766848510.33 & 20094.07 & & \\
\hline
\end{tabular}


Effects on Labour and GDP of the CAP 2013 reform though investment in agricultural machinery: Spanish case

Table 7 Machinery (disaggregated)

\begin{tabular}{|c|c|c|c|c|}
\hline Year & $\begin{array}{l}\text { 4. Total } \\
\text { Machinery }\end{array}$ & $\begin{array}{l}\text { 4.1. Agricultural, farmer } \\
\text { and fishing machinery }\end{array}$ & $\begin{array}{l}\text { 4.2. Metal } \\
\text { machinery }\end{array}$ & $\begin{array}{l}\text { 4.3. Other machinery } \\
\text { and software }\end{array}$ \\
\hline 1977 & 106511785.42 & 927090.59 & 103205274.59 & 2379420.25 \\
\hline 1978 & 110439850.45 & 1067079.38 & 106805342.25 & 2567428.81 \\
\hline 1979 & 113157036.40 & 1203035.25 & 109222932.19 & 2731068.96 \\
\hline 1980 & 115717706.15 & 1348443.77 & 111432971.48 & 2936290.90 \\
\hline 1981 & 117394790.32 & 1497529.14 & 112763768.59 & 3133492.59 \\
\hline 1982 & 118172290.09 & 1649123.84 & 113246356.24 & 3276810.01 \\
\hline 1983 & 118587111.66 & 1802957.22 & 113309468.69 & 3474685.75 \\
\hline 1984 & 118620638.30 & 1882459.96 & 113026428.98 & 3711749.37 \\
\hline 1985 & 119867922.48 & 1935207.87 & 113878132.81 & 4054581.80 \\
\hline 1986 & 122616062.95 & 2188496.97 & 115892254.73 & 4535311.25 \\
\hline 1987 & 127995437.10 & 2373129.41 & 120565044.85 & 5057262.84 \\
\hline 1988 & 135704342.94 & 2557290.23 & 127493787.00 & 5653265.71 \\
\hline 1989 & 145123075.12 & 2574740.57 & 136038150.51 & 6510184.04 \\
\hline 1990 & 154017409.78 & 2429078.16 & 144239561.39 & 7348770.23 \\
\hline 1991 & 161443798.68 & 2283080.55 & 151169427.75 & 7991290.39 \\
\hline 1992 & 167572589.36 & 2133043.63 & 156901711.21 & 8537834.52 \\
\hline 1993 & 168900134.24 & 1993047.84 & 157960112.80 & 8946973.60 \\
\hline 1994 & 170172985.80 & 1899887.28 & 158918264.09 & 9354834.43 \\
\hline 1995 & 173384637.44 & 1823598.14 & 161732490.03 & 9828549.26 \\
\hline 1996 & 179502899.35 & 2155025.10 & 166993184.24 & 10354690.01 \\
\hline 1997 & 187722611.78 & 2387660.03 & 174431154.35 & 10903797.41 \\
\hline 1998 & 200835756.13 & 2588335.04 & 186502783.73 & 11744637.36 \\
\hline 1999 & 216826588.15 & 2826368.07 & 200956142.89 & 13044077.19 \\
\hline 2000 & 234745387.95 & 3098937.40 & 217049235.36 & 14597215.20 \\
\hline 2001 & 251371224.76 & 3349588.50 & 232095748.70 & 15925887.56 \\
\hline 2002 & 265820707.96 & 3585726.69 & 245213324.91 & 17021656.35 \\
\hline 2003 & 280604757.59 & 3803840.75 & 258228102.74 & 18572814.10 \\
\hline 2004 & 295740763.08 & 4001678.74 & 271253508.97 & $20485575 \cdot 38$ \\
\hline 2005 & 314828715.40 & 4226887.24 & 287507945.47 & 23093882.69 \\
\hline
\end{tabular}




\section{Appendix II. Multivariate Models.}

\begin{tabular}{c|c|c}
\multicolumn{4}{c}{$\widehat{\Pi}_{\mathrm{w}}^{*}(\mathrm{~B}) \mathrm{w}_{\mathrm{t}}=\widehat{\mathrm{a}}_{\mathrm{t}}^{*}$} \\
\hline$\widehat{\Pi}_{\mathrm{w}}^{*}(\mathrm{~B})$ & $\mathrm{w}_{\mathrm{t}}$ & $\hat{\mathrm{a}}_{\mathrm{t}}^{*}$ \\
\hline$\left[\begin{array}{ll}\widehat{\Pi}_{\mathrm{w}_{11}}^{*}(\mathrm{~B}) & \widehat{\Pi}_{\mathrm{w}_{12}}^{*}(\mathrm{~B}) \\
\widehat{\Pi}_{\mathrm{w}_{21}}^{*}(\mathrm{~B}) & \widehat{\Pi}_{\mathrm{w}_{22}}^{*}(\mathrm{~B})\end{array}\right]$ & $\left(\begin{array}{c}y_{t} \\
l_{t} \\
\bar{k}_{i_{t}} \\
k_{i_{t}}\end{array}\right)+\left(\begin{array}{c}-0.01 \\
0 \\
0 \\
0\end{array}\right)$ & $\left(\begin{array}{c}\hat{\mathrm{a}}_{y_{t}}{ }^{*} \\
\hat{\mathrm{a}}_{l_{t}}^{*} \\
\hat{\mathrm{a}}_{\bar{k}_{i_{t}}}{ }^{*} \\
\hat{\mathrm{a}}_{k_{i_{t}}}^{*}\end{array}\right)$ \\
\hline
\end{tabular}

Table 8 Orthogonalized Reduced Forms

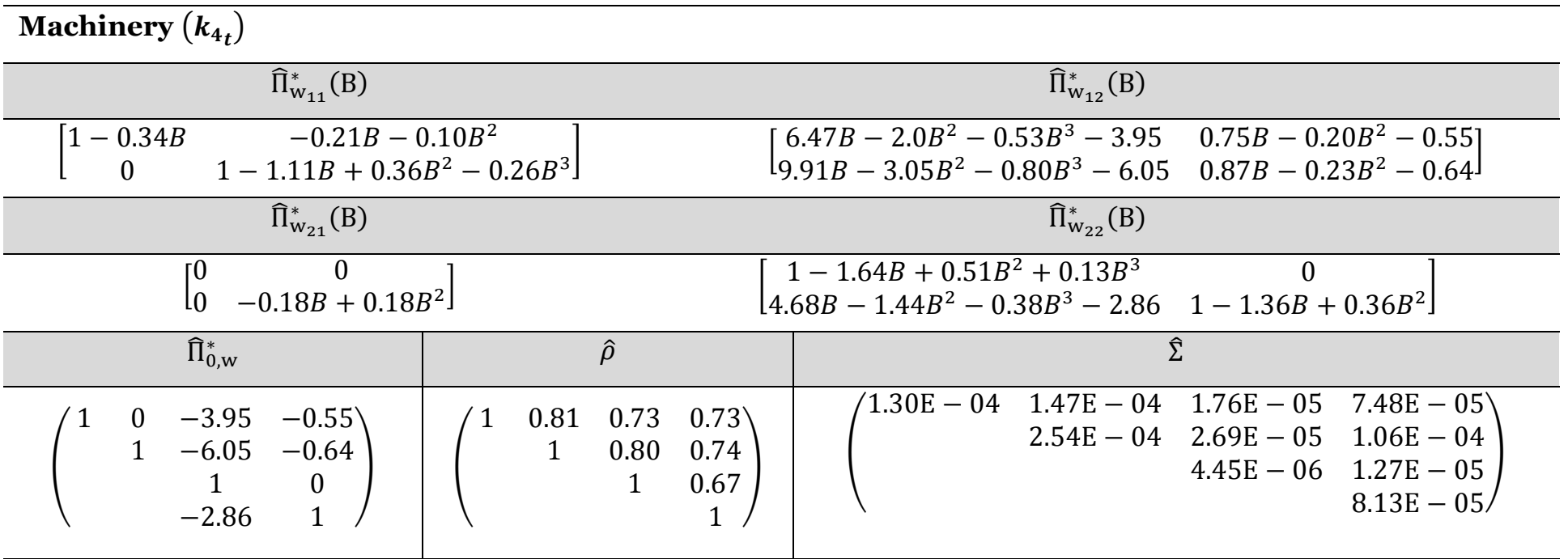

Agricultural, farmer and fishing machinery $\left(k_{4_{1} t}\right)$

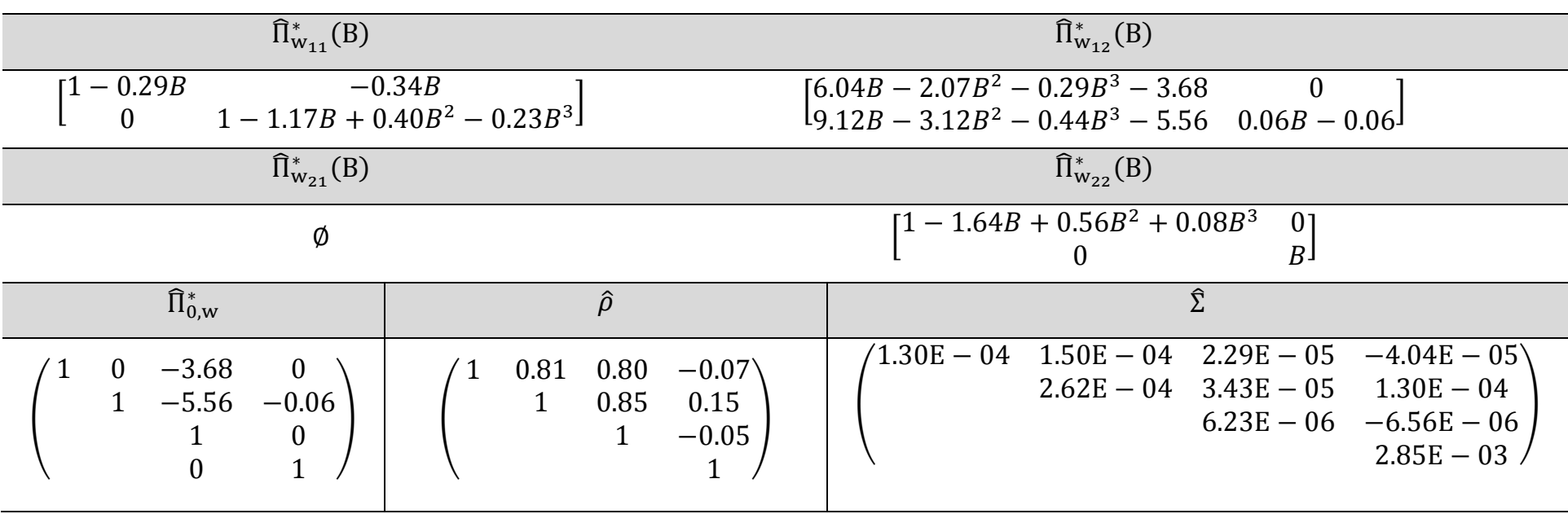


Effects on Labour and GDP of the CAP 2013 reform though investment in agricultural machinery: Spanish case

Metal machinery $\left(k_{4_{2} t}\right)$

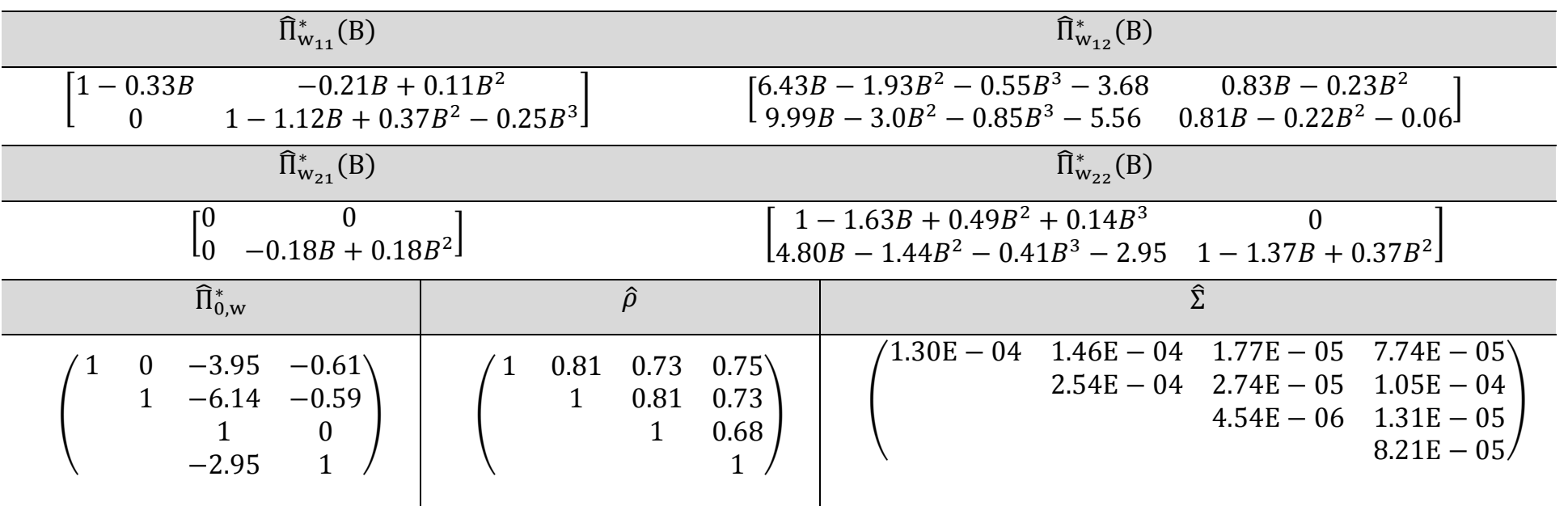

Non-specialized machinery and software $\left(k_{4_{3} t}\right)$

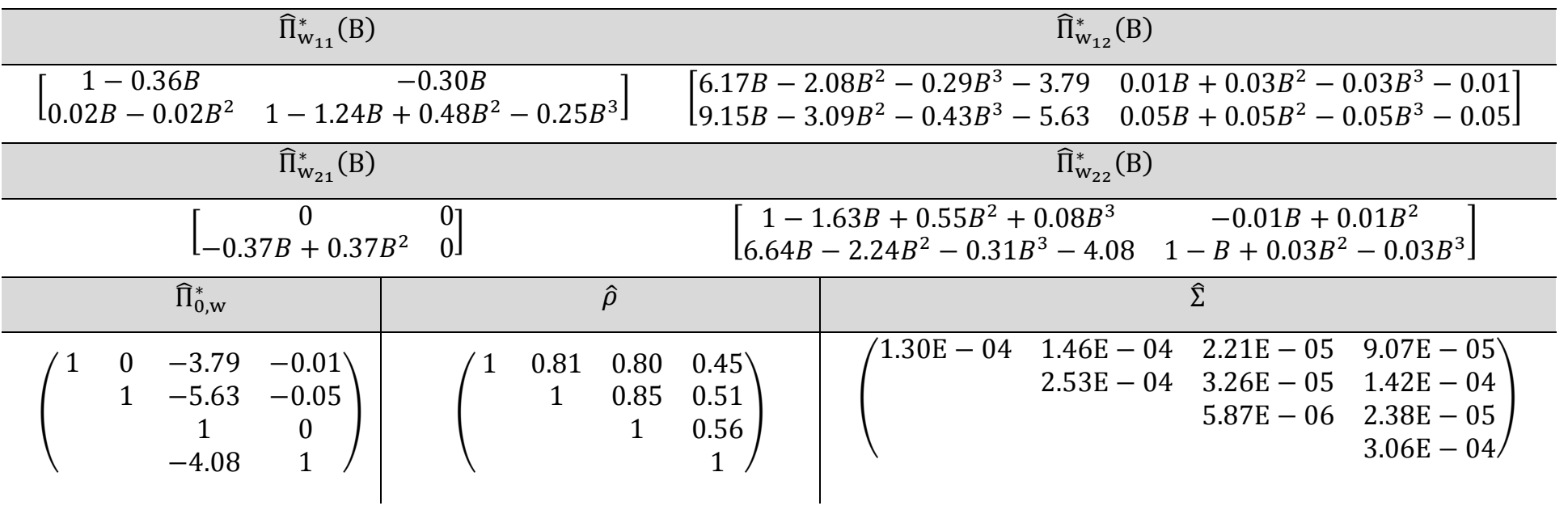




\section{Appendix III. Mathematical appendix.}

From the estimation of $\Sigma=\mathrm{E}\left(\mathrm{a}_{\mathrm{t}}, \mathrm{a}_{\mathrm{t}}^{\prime}\right)$ in (20)

$$
\Sigma=\left(\Pi^{+}(0)\right)^{-1} \Sigma^{+}\left(\Pi^{+}(0)\right)^{-1^{\prime}}
$$

or

$$
\begin{aligned}
\left(\begin{array}{cc}
\Sigma_{11} & \Sigma_{12} \\
\Sigma_{21} & \Sigma_{22}
\end{array}\right) & =\left(\begin{array}{cc}
\mathrm{I} & v_{\mathrm{z} 0} \mathrm{P}_{\mathrm{k}}^{-1} \\
0 & \mathrm{P}_{\mathrm{k}}^{-1}
\end{array}\right)\left(\begin{array}{cc}
\Sigma_{\mathrm{z}} & 0 \\
0 & \Sigma_{\mathrm{k}}^{+}
\end{array}\right)\left(\begin{array}{cc}
\mathrm{I} & 0 \\
\mathrm{P}_{\mathrm{k}}^{-1^{\prime}} v_{\mathrm{z} 0}^{\prime} & \mathrm{P}_{\mathrm{k}}^{-1^{\prime}}
\end{array}\right)= \\
= & \left(\begin{array}{cc}
\Sigma_{\mathrm{z}} & v_{\mathrm{z} 0} \mathrm{P}_{\mathrm{k}}^{-1} \Sigma_{\mathrm{k}}^{+} \\
0 & \mathrm{P}_{\mathrm{k}}^{-1} \Sigma_{\mathrm{k}}^{+}
\end{array}\right)\left(\begin{array}{cc}
\mathrm{I} & 0 \\
\mathrm{P}_{\mathrm{k}}^{-1^{\prime}} v_{\mathrm{z} 0}^{\prime} & \mathrm{P}_{\mathrm{k}}^{-1^{\prime}}
\end{array}\right)= \\
& =\left(\begin{array}{cc}
\Sigma_{\mathrm{z}}+v_{\mathrm{z} 0} \mathrm{P}_{\mathrm{k}}^{-1} \Sigma_{\mathrm{k}}^{+} \mathrm{P}_{\mathrm{k}}^{-1^{\prime}} v_{\mathrm{z} 0}^{\prime} & \mathrm{P}_{\mathrm{k}}^{-1} \Sigma_{\mathrm{k}}^{+} \mathrm{P}_{\mathrm{k}}^{-1^{\prime}} v_{\mathrm{z} 0}^{\prime} \\
v_{\mathrm{z} 0} \mathrm{P}_{\mathrm{k}}^{-1} \Sigma_{\mathrm{k}}^{+} \mathrm{P}_{\mathrm{k}}^{-1^{\prime}} & \mathrm{P}_{\mathrm{k}}^{-1} \Sigma_{\mathrm{k}}^{+} \mathrm{P}_{\mathrm{k}}^{-1^{\prime}}
\end{array}\right)=
\end{aligned}
$$

Then:

$$
\begin{gathered}
\Sigma_{11}=\Sigma_{\mathrm{z}}+v_{\mathrm{z} 0} \mathrm{P}_{\mathrm{k}}^{-1} \Sigma_{\mathrm{k}}^{+} \mathrm{P}_{\mathrm{k}}^{-1^{\prime}} v_{\mathrm{z} 0}^{\prime} \\
\Sigma_{12}=\mathrm{P}_{\mathrm{k}}^{-1} \Sigma_{\mathrm{k}}^{+} \mathrm{P}_{\mathrm{k}}^{-1^{\prime}{ }^{\prime} v_{\mathrm{z} 0}^{\prime}} \\
\Sigma_{22}=\mathrm{P}_{\mathrm{k}}^{-1} \Sigma_{\mathrm{k}}^{+} \mathrm{P}_{\mathrm{k}}^{-1^{\prime}} \\
\Sigma_{\mathrm{z}}=\Sigma_{11}-\Sigma_{12} \\
v_{\mathrm{z} 0}=\Sigma_{12} \Sigma_{22}^{-1} \\
\Sigma_{22}=\left(\begin{array}{cc}
1 & 0 \\
-\beta & 1
\end{array}\right)\left(\begin{array}{ccc}
\sigma_{\bar{k}_{i}}^{2} & 0 \\
0 & \sigma_{k_{i}}^{2}
\end{array}\right)\left(\begin{array}{cc}
1 & -\beta \\
0 & 1
\end{array}\right)=\left(\begin{array}{cc}
\sigma_{\bar{k}_{i}}^{2} & 0 \\
-\beta \sigma_{\bar{k}_{i}}^{2} & \sigma_{k_{i}}^{2}
\end{array}\right)\left(\begin{array}{cc}
1 & -\beta \\
0 & 1
\end{array}\right)=\left(\begin{array}{ll}
\sigma_{11} & \sigma_{12} \\
\sigma_{21} & \sigma_{22}
\end{array}\right)= \\
=\left(\begin{array}{cc}
\sigma_{\bar{k}_{i}}^{2} & -\beta \sigma_{\bar{k}_{i}}^{2} \\
-\beta \sigma_{\bar{k}_{i}}^{2} & -\beta \sigma_{\bar{k}_{i}}^{2}+\sigma_{k_{i}}^{2}
\end{array}\right)
\end{gathered}
$$


Effects on Labour and GDP of the CAP 2013 reform though investment in agricultural machinery: Spanish case

Matching terms

$$
\begin{gathered}
\sigma_{11}=\sigma_{\bar{k}_{i}}^{2} ; \sigma_{12}=\sigma_{21}=-\beta \sigma_{\bar{k}_{i}}^{2} ; \sigma_{22}=-\beta \sigma_{\bar{k}_{i}}^{2}+\sigma_{k_{i}}^{2} \\
\beta=-\frac{\sigma_{12}}{\sigma_{11}}
\end{gathered}
$$

So all the elements of $\Pi^{+}(0)$ can be estimated across the following relationships

$$
\begin{gathered}
\Pi^{+}(0)=\left[\begin{array}{cc}
\mathrm{I} & -v_{\mathrm{z} 0} \\
0 & \mathrm{P}_{\mathrm{k}}
\end{array}\right] \\
-v_{\mathrm{z} 0}=-\Sigma_{12} \Sigma_{22}^{-1} ; \mathrm{P}_{\mathrm{k}}=\left[\begin{array}{cc}
1 & 0 \\
-\frac{\sigma_{12}}{\sigma_{11}} & 1
\end{array}\right]
\end{gathered}
$$

Thus, estimating $\Pi^{+}(0)$ across (21) it is possible to estimate $\Pi^{+}(\mathrm{B})$ as $\Pi^{+}(\mathrm{B})=$ $\Pi^{+}(0) \Pi(B)$, and from $\Pi^{+}(B)$ to estimate $\Psi^{+}(B)$ as $\Psi^{+}(B)=\left[\Pi^{+}(B)\right]^{-1}$ 